TEXT Volume 13 No 2 October 2009

\title{
Editorial
}

\section{A new era jostle}

It has been clear for 26 issues of TEXT that the doctoral exegesis is a key generator of refereed articles (as too some Honours and Masters exegeses). Ali Alizadeh, Bunty Avieson, Inez Baranay, Gareth Beal - to name only the first four in an alphabetical list - turned their doctoral exegeses into refereed articles. These stand alongside the rare academic book produced from candidature in our area, such as Paul Dawson's Creative Writing and the New Humanities (2005) which derived from his University of Melbourne doctoral thesis. The creative works published commercially out of doctoral submissions (more than $50 \%$ of doctoral creative works achieve publication, according to Boyd in our last issue) have not had the same research kudos as the exegeses.

To date focus of the doctoral exegesis has been directed toward research publication, and the creative component toward commercial publication. But things are about to change. The creative product will soon be bone fide, money-in-the-pocket research. With original works now included in ERA indicators alongside the more academic outputs normally published in TEXT, a new scenario emerges. All those novels, playscripts, collections of stories and poems produced for research higher degrees will become reportable in ERA. Of course, for each work the case must be made successfully to the ARC's peer reviewers in the accompanying statement of how it constitutes a contribution to knowledge. But it's unlikely that an original creative work which is part of a successful doctoral (or other) research degree submission could be rejected by the ARC as not research. Need a successful candidate even make a case? If a novel or script has been awarded a research degree, surely it has research status.

It is therefore a new area of research that TEXT now enters. In the past the question of refereed creative works has been contentious - some universities have had special arrangements to count them as research, while others have not. Once ERA kicks in (provided they don't kick the whole idea out, of course, following the 2009 trial) creative research works will vie vigorously for space amongst the crowd of traditional refereed articles.

The word 'era' appears in another context in the scholarly writing community this year. Mark McGurl's new book, The Program Era: Postwar Fiction and the Rise of Creative Writing (Harvard University Press), identifies tertiary writing programs as key contributors to postwar American literature. This is refreshing news in an era (that word again) where creative writing academics are more used to hearing about the damage we risk doing to the literary culture. In a review essay on the book for the Chronicle of Higher Education, 'An era of detente for creative writing programs',[1] Jennifer Howard outlines central elements of McGurl's thesis, and names as evidence of the quality output of writing programs authors like Michael Chabon, Richard Russo, David Foster Wallace, Jeffrey Eugenides. We could add to her list British-trained authors 
such as Andrew Motion, Tracey Chevalier, Ian McEwan, Kazuo Ishiguro; or Australians like Venero Armanno, Steve Conte, Mary Rose MacColl, Tim Winton; or New Zealanders like Jenny Bornholdt, Elizabeth Knox, Damien Wilkins, Catherine Chidgey. While writing programs in each nation have their own ways of managing creative writing in tertiary education, they have shared concerns, shared interests and, in a globalised economy, shared imperatives and contexts. Further research into the fit between writing programs, publishing industries and tertiary education is likely to prove productive.

This issue takes on questions of program direction, research activity, and the creative life in 11 essays. Nigel Krauth's 'The supervisor as editor' teases out the complexities of that relationship; Paul Magee reports on the findings of his research into another complex relationship - that between the production of poetry and the production of knowledge. Mike Harris, Gaylene Perry and Dan Disney all take issue with the focus of teaching in creative writing programs: Harris and Disney raising the problems they perceive in particular theoretical orientations, and Perry identifying shortcomings in the creative industries when applied to writing. Donna Lee Brien investigates the intersection of real and fictional stories in the writing of stories that are based on real lives, Emily Sutherland and Tony Gibbons deal in similar material in the relationship between history and historical fiction, and Sandra Arnold writes movingly on the bereaved parents of adult children and how they use writing to confront their loss. Carolyne Lee explores that sometimes undervalued form, the short story, Keith Harrison gives an account of the writing of his novel Eyemouth, and Michael Wilding's fiction piece acts as a cautionary tale for writers in the academy.

There is also a healthy group of poems in this issue, with works by Maggie Butt, Barbara Edwards, Sue King-Smith, Jeff Klooger and Andrew Slattery; and finally, Donna Lee Brien, Dominique Hecq, Bronwen Levy, Sandra Burr and RA Goodrich review recent books of interest to writers and members of writing programs.

Nigel Krauth

Jen Webb

1. Howard, Jennifer 2009 'An era of detente for creative-writing programs', Chronicle of Higher Education vol 55, 29 June return to text

\section{TEXT}

Vol 13 No 2 October 2009

http://www.textjournal.com.au

Editors: Nigel Krauth \& Jen Webb

Text@griffith.edu.au 